NOW showed very high sensitivity for detection of patients with high levels of SARS-CoV-2 RNA but lower overall sensitivity compared with the Xpert SARS-CoV-2 assay. In our evaluation, the 2 cases of disagreement with the Abbott RealTime SARS-CoV-2 assay had high Ct values, indicating the presence of low viral loads.

Considering that low-viral-load samples are commonly unable for viral growth in cell cultures, ${ }^{9}$ the clinical impact of ID NOW should be approached with respect to the advantage of saving time in detecting infected patients and the disadvantage of false negatives with lower viral loads. Even though IATs are not yet ready to entirely replace real-time RT-PCR, the implementation of assays such as ID NOW could be beneficial in reducing turnaround times, especially in emergency departments, as well as the overall costs of SARS-CoV-2 detection.

\section{Acknowledgments.}

Financial support. No financial support was provided relevant to this article.

Conflicts of interest. All authors report no conflicts of interest relevant to this article.

\section{References}

1. Lim J, Lee J. Current laboratory diagnosis of coronavirus disease 2019. Korean J Intern Med 2020;35:741-748.

2. James AS, Alawneh JI. COVID-19 infection diagnosis: potential impact of isothermal amplification technology to reduce community transmission of SARS-CoV-2. The carbapenemase menace: do dual mechanisms code for more resistance? Diagnostics (Basel) 2020;10:399.

3. Canadian Public Health Laboratory Network and the Canadian Society of Clinical Chemists. Interim guidance on the use of the Abbott ID NOW instrument and COVID-19 assay. Can Commun Dis Rep 2020; 46:422-426.

4. Office of the Commissioner. Coronavirus (COVID-19) update: FDA informs public about possible accuracy concerns with Abbott ID NOW point-of-care test. US Food and Drug Administration website. https://www.fda.gov/newsevents/press-announcements/coronavirus-covid-19-update-fda-informs-publicabout-possible-accuracy-concerns-abbott-id-now-point. Published 2020. Accessed July 3, 2021.

5. Basu A, Zinger T, Inglima K, et al. Performance of Abbott ID Now COVID-19 rapid nucleic acid amplification test using nasopharyngeal swabs transported in viral transport media and dry nasal swabs in a New York City academic institution. J Clin Microbiol 2020;58:e01136-20.

6. Harrington A, Cox B, Snowdon J, et al. Comparison of Abbott ID Now and Abbott m2000 methods for the detection of SARS-CoV-2 from nasopharyngeal and nasal swabs from symptomatic patients. J Clin Microbiol 2020;58: e00798-20.

7. Smithgall MC, Schebekova I, Whitter S, Green DA. Comparison of Cepheid Xpert Xpress and Abbott ID Now to Roche cobas for the rapid detection of SARS-CoV-2. J Clin Virol 2020;128:104428.

8. Zhen W, Smith E, Manji R, Schron D, Berry GJ. Clinical evaluation of three sample-to-answer platforms for detection of SARS-CoV-2. J Clin Microbiol 2020;58:e00783-20.

9. Sepulveda JL, Abdulbaki R, Sands Z, et al. Performance of the Abbott ID NOW rapid SARS-CoV-2 amplification assay in relation to nasopharyngeal viral RNA loads. J Clin Virol 2021;140:104843.

\title{
Challenges associated with using cycle threshold (Ct) value of reverse-transcription polymerase chain reaction (RT-PCR) as a criteria for infectiousness of coronavirus disease 2019 (COVID-19) patients in India
}

\author{
Saad Ahmed Jamal MBBS (1), Mir Umar Farooq MBBS and Vishwanath Bidari MBBS
}

To the Editor-We read with great interest the article "COVID-19 Admission Screening, and Assessment of Infectiousness at an Academic Medical Center, Iowa 2020" by Alsuhaibani et al, ${ }^{1}$ in which the cycle threshold $(\mathrm{Ct})$ value of severe acute respiratory coronavirus virus 2 (SARS-CoV-2) reverse-transcription polymerase chain reaction (RT-PCR) was one of the criteria used to determine the degree of infectiousness in patients.

Having suffered a disastrous second wave resulting from a severe shortage of resources, India ranks 155 of 167 countries, with 5 hospital beds and 8.6 doctors per 10,000 people. ${ }^{2}$ With health experts predicting an impending third wave, it is essential for hospital administrations to revise admission criteria and triage policies. One criterion that has garnered attention is the $\mathrm{Ct}$ value of

Author for correspondence: Dr. Saad Ahmed Jamal (M.B.B.S.), E-mail : saad.gx@ gmail.com

Cite this article: Jamal SA, Farooq MU, and Bidari V. (2022). Challenges associated with using cycle threshold $(\mathrm{Ct})$ value of reverse-transcription polymerase chain reaction (RT-PCR) as a criteria for infectiousness of coronavirus disease 2019 (COVID-19) patients in India. Infection Control \& Hospital Epidemiology, 43: 1730-1731, https:// doi.org/10.1017/ice.2021.357
SARS-CoV-2 RT-PCR tests. However, many challenges are associated with using $\mathrm{Ct}$ values as a reliable criterion for infectiousness.

The Ct value is the cycle of amplification at which fluorescence indicates a positive result. ${ }^{3}$ It is explained as the number of cycles of amplification of viral copies it takes for the RT-PCR to register a positive test. The $\mathrm{Ct}$ score is inversely proportional to the viral load present within the sample.

The widely used RT-PCR testing for SARS-CoV-2 utilizes nasal or nasopharyngeal samples via swab collection. One of the important issues with using $\mathrm{Ct}$ value as an indicator of infectiousness is the variation in the skill of the swab collectors, along with the tolerance of the patients. Having faced a huge shortage of healthcare workers, state governments across India have employed swab collectors from various professions as well as students outside health care to cope with shortage of manpower, training them for 3-5 days. ${ }^{4}$ The skill level of these swab collectors varies greatly. A news article from the city of Bengaluru reported one case of a student volunteer who collected 385 samples over 5 hours. ${ }^{5}$ Although this procedure speeds testing, it also leads to the collection of imprecise quantities of samples. Dahdouh et $\mathrm{al}^{6}$ reinforced the large amount of variation in samples 
collected from a nasopharyngeal surface. There may be a difference between the amount of virus collected and the amount of virus present within the nasopharynx of an individual, which is dependent largely on the swab collector. Therefore, they recommend that these variations be corrected with markers that should be integrated with commercial tests to standardize results. ${ }^{6}$

Notably, different laboratories have implemented different $\mathrm{Ct}$ value thresholds at which a negative test is declared. Globally, a Ct threshold of 37-40 is regarded as the cutoff, above which a test is considered negative. However, in the state of Maharashtra in India, the most severly affected state in India, the Indian Council of Medical Research (ICMR) recommended a Ct threshold value of 35. According to the state government of Maharashtra, certain laboratories were using a Ct value of 24, and any higher value was declared negative. ${ }^{7}$ These assessments created a dangerous situation because the patients with Ct values between 24 and 35 , who would otherwise test positive, escaped further follow-up. Thus, this population skipped the 14-day quarantine period for COVID-19-positive patients and moved through the public as unknown carriers of the virus, leading to further spread.

Also, Ct value thresholds vary widely among different commercial kits, and in some cases, even among different runs of the same kits. ${ }^{8}$ To deal with these variations, qualitative RT-PCR test kits and $\mathrm{Ct}$ values should not be used as a replacement for quantitative RT-PCR to determine the viral load of a patient. Rather, a 2-step approach using qualitative RT-PCR for detection followed by a quantitative RT-PCR to detect viral load should be employed as demonstrated. ${ }^{9}$ In addition, appropriate units should be employed for quantification (eg, copies $/ \mathrm{mL}$ ) rather than Ct values. ${ }^{9}$

Another issue with using $\mathrm{Ct}$ values as a criterion for infectiousness is that it varies depending upon the timing of the illness at which the swab is taken. Ct values were lower when samples were collected early in the illness and were higher when taken in the later stages of illness. ${ }^{10}$ Furthermore, a study conducted in India to investigate a link between severity of COVID-19 and Ct value also demonstrated that Ct values varied depending on the duration of illness, rather than severity of the disease. Those who were tested earlier in their illness had a lower Ct value than patients whose samples taken later in their illness. ${ }^{11}$

The Ct value has attracted widespread attention from the general public in India. It has been observed that patients, although asymptomatic, are quick to seek admission since they fear a low Ct value implies a high severity of illness. This problem has been coupled with the severe scarcity of beds and resources, which has placed great strain on the healthcare system. ${ }^{12}$ Symptomatic patients requiring medical attention are often shunned from hospitals due to a shortage of hospital beds. On the other hand, those with higher Ct values are often equipped with a false sense of security and tend to flout quarantine and isolation rules.

In conclusion, the $\mathrm{Ct}$ value is an important tool that can be used to aid contact tracing and isolation. However, it is necessary to understand its limitations in low-income and low-tomiddle-income countries like India because using the $\mathrm{Ct}$ value as a quantitative indicator of infectiousness has several disadvantages.

\section{References}

1. COVID-19 admission screening, and assessment of infectiousness at an academic medical center, Iowa 2020. Infect Control Hosp Epidemiol 2021. doi: 10.1017/ice.2021.294.

2. Nagarajan R. 5 hospital beds/10k population: India ranks 155 th in 167 . The Times of India website. https://timesofindia.indiatimes.com/india/5hospital-beds/10k-population-india-ranks-155th-in-167/articleshow/ 79769527.cms. Accessed July 30, 2021.

3. Landry ML. Your coronavirus test is positive. Maybe it shouldn't be. New York Times, August 29, 2020.

4. Khanna B. Short of hands, BBMP looks for COVID volunteers. The New Indian Express website. https:/www.newindianexpress.com/cities/ bengaluru/2020/jul/23/short-of-hands-bbmp-looks-for-covid-volunteers2173503.html. Accessed July 30, 2021.

5. Sunitha RR. Bengaluru: student swab collector takes staggering 385 samples in 5 hours. The Times of India website. https://timesofindia.indiatimes.com/ city/bengaluru/student-swab-collector-takes-staggering-385-samples-in-5hours/articleshow/78756190.cms. Accessed July 30, 2021.

6. Dahdouh E, Lázaro-Perona F, Romero-Gómez MP, Mingorance J, GarcíaRodriguez J. Ct values from SARS-CoV-2 diagnostic PCR assays should not be used as direct estimates of viral load. J Infect 2021;82:414-451.

7. Patwardhan R, Kelkar R. Virus alert. The Indian Express website. https:// indianexpress.com/article/opinion/virus-alert-covid-ct-value-7363672/. Published June 17, 2021. Accessed July 30, 2021.

8. Han MS, Byun J-H, Cho Y, Rim JH. RT-PCR for SARS-CoV-2: quantitative versus qualitative. Lancet Infect Dis 2021;21:165.

9. Lescure FX, Bouadma L, Nguyen D, et al. Clinical and virological data of the first cases of COVID-19 in Europe: a case series. Lancet 2020;20:697-706.

10. Wölfe, R, Corman VM, Guggemos W, et al. Virological assessment of hospitalized patients with COVID-2019. Nature 2020;581:465-469.

11. Shah S, Singhal T, Davar N, Thakkar P. No correlation between Ct values and severity of disease or mortality in patients with COVID 19 disease. Indian J Med Microbiol 2021;39:116-117.

12. Madhavan R. Asymptomatic patients filling up beds, say doctors. The New Indian Express website. https:/www.newindianexpress.com/cities/ bengaluru/2020/jul/24/asymptomatic-patients-filling-up-beds-say-doctors2174010.html. Published July 24, 2020. Accessed July 30, 2021. 